\title{
How EXPENSIVE TransParent LOBbying IS
}

\author{
Pavla Bednářová \\ Technical University of Liberec, Faculty of Economics, Department of Economics, \\ Voroněžská 13, 46001 Liberec 1, Czech Republic \\ e-mail: pavla.bednarova@tul.cz
}

\begin{abstract}
Strengthening the transparency of the legislation and decision making process should contribute to the reduction of negative impacts often connected with lobbying. The aim of the article was to determine options for lobbying transparency increase and their evaluation from the viewpoint of regulatory costs. Cost Benefit Analysis (CBA) which is the core method of Regulatory Impact Analysis (RIA), is used. The basic options were determined. Zero option was defined as the preservation of the current legislation and non-transparent lobbying. Option I is the possibility of increasing the transparency of lobbying by introducing measures related to lobbyists. Option II represents an increase of transparency in terms of lobbying targets. Option III is defined as an increase in lobbying transparency by means of sunshine principles; the increase of lobbying transparency by monitoring and sanctions is included in Option IV. Regulatory costs, specifically the compliance costs and other regulatory costs, have been defined for all five options.
\end{abstract}

\section{Keywords}

Transparency; Lobbying; Regulatory impact analysis; Cost benefit analysis; Regulatory costs.

\section{Introduction}

The article has been written as an integral part of the evaluation of the project focused on lobbying transparency increase as part of the GAČR grant "Impact of Transparency of Lobbying on Democratization and Its Consequences". The aim of the article is to identify the costs associated with transparent lobbing: to determine options for lobbying transparency increase and their evaluation from the viewpoint of regulatory costs.

Lobbying as a term can be defined in various ways. In essence, however, it always involves advancing of interests of a particular interest group in the course of a decision making process. A definition which is often considered as the most precise is that by L. Graziano [1:248]:

"Lobbying is a specialised and professional representation of interests by means of a wide variety of tools which in principle eliminate a corruptive change of services. It is by its nature very different from a general non-specialised representation provided by elected representatives. As a representative of particular interests a lobbyist provides information and technically-professional expertises which can be useful and sometimes decisive for defining legislative and administrative regulation."

In addition to this, there is Van Schendelen's [2:210] definition stating that

"Lobbying refers to the various types of unconventional behaviour of interest groups focused on achieving requested results." 
In 2006, the European Commission (further just as Commission) issued a document called Green Book - European Transparency Initiative. This document [3:5] formulates a relatively broad definition of lobbying as

"all activities carried out with the objective of influencing the policy formulation and decision-making processes of the European institutions."

Š. Laboutková and M. Žák [4:2] delimited the basic attributes of lobbying when they stated that

"Lobbying is first of all focused on advancing interests, it is an indispensable source of information and the biggest problem is to distinguish lobbying from corruption."

\section{$1 \quad$ Aims of the Research}

Lobbying helps to articulate and advance interests of various parts of society and it is at the same time an information channel by means of which the knowledge of the public authorities about decisive facts is improved. Affecting representatives of public authorities with the aim to influence their decisions is not always transparent and according to clear rules, which brings the risk of the public interests being manipulated in favour of hidden partial interests. Strengthening the transparency of the legislation and decision making process helps to reveal the influence and the relations between lobbyists and interest groups on the one hand and public entities on the other hand to public control, which should contribute to the reduction of negative impacts often connected with lobbying, such as corruption, conflict of interests, protection and clientelism. According to OECD [5], creating limits for transparent lobbying is also essential for the integrity of the public decision making process.

Š. Laboutková a P. Vymětal [6] proposed a catalogue of currently used measures dealing directly or indirectly with lobbying regulation that support the transparency principle in general. All measures are grouped in four logical categories, see Tab. 1.

An important reason for improving the tools for the lobbying transparency increase is the dynamics of lobbying regulatory activities, especially in Europe. According to current tendencies within European countries, very dynamic regulatory activities of lobbying can be expected. Regulation can be supportive of market transactions and may result in significant economic, social and environmental benefits. At the same time, ill-designed regulations can have considerable economic costs, resulting in the concept of the "regulatory burden". The aim of the article is to identify the costs associated with transparent lobbying: to determine options for lobbying transparency increase, their evaluation and comparison from the viewpoint of regulatory costs. 
Tab. 1: Main categories on lobbyists' transparency

\begin{tabular}{|c|c|c|c|}
\hline Category & Chapter & Data / Information & $\begin{array}{l}\text { Number of } \\
\text { indicators }\end{array}$ \\
\hline \multirow{4}{*}{ Lobbyists } & 1 & Register & 14 \\
\hline & 2 & Codes of Conduct & 8 \\
\hline & 3 & Disclosure of activities & 7 \\
\hline & 4 & Open calendars & 2 \\
\hline \multirow{5}{*}{$\begin{array}{l}\text { Targets of } \\
\text { lobbying }\end{array}$} & 5 & Codes of Conduct & 14 \\
\hline & 6 & Revolving doors & 7 \\
\hline & 7 & Conflict of interests & 5 \\
\hline & 8 & Disclosures of politicians/senior public employees & 3 \\
\hline & 9 & Appointment diaries & 9 \\
\hline \multirow{7}{*}{$\begin{array}{l}\text { Sunshine } \\
\text { principles / } \\
\text { sunshine rule }\end{array}$} & 10 & Rules on legislative process & 17 \\
\hline & 11 & Rules on decision-making & 6 \\
\hline & 12 & Rules on consultations & 10 \\
\hline & 13 & Legislative footprint & 6 \\
\hline & 14 & Open Government Data & 12 \\
\hline & 15 & Political parties funding & 9 \\
\hline & 16 & Freedom of information & 10 \\
\hline \multirow{2}{*}{$\begin{array}{l}\text { Monitoring and } \\
\text { sanctioning }\end{array}$} & 17 & Oversight & 7 \\
\hline & 18 & Sanctions & 13 \\
\hline
\end{tabular}

Source: [6]

\section{Methods of the Research}

As far as the evaluation of the lobbying transparency increase is concerned, the most commonly used are input-output methods that include economic analyses, specifically Cost Benefit Analysis (CBA), which is the core method of Regulatory Impact Analysis (RIA). RIA is a systemic approach to critically assessing the positive and negative effects of proposed and existing regulations and non-regulatory alternatives. The economic rationale for the use of RIA derives from its expected impact on increasing the effectiveness and efficiency of regulatory interventions and thus economic welfare. The economics of regulation presents three different dynamics that explain the rationale for the adoption of RIA. The first is delegation. Regulatory intervention is characterised by a problem of delegation when a principal (the parliament or other legislative authorities) delegates authority to produce regulation to an agent (i.e. a ministry or other agencies). In rational choice theory $[7,8]$ the principal-agent model helps in understanding the rationale for RIA. Once power has been delegated, information asymmetries produce agency dominance, and agencies may produce rules that do not reflect the approach adopted (or outcome sought) by the principals. However, the likelihood that agencies will develop rules that are consistent with the views of the principals is enhanced if proper administrative procedures (such as RIA) are introduced [9]. Posner [10] suggests that CBA should be used to control agency behaviour, minimising error costs under conditions of information asymmetry. Thus, the use of RIA limits the potential influence of self-seeking interest groups by reducing the principal-agent slack and in assuring that agencies are responsive to the principal's interest. The second is democratic governance. Neo-pluralist theory $[11,12]$ suggests that regulatory policy tools (such as RIA) should be used to change the framework in which actors (the executive, agencies, and the pressure 
groups, including civil society associations) interact so that the rulemaking process is more open to diffuse interests and more accountable to citizens. RIA is adopted to help to ensure that all the major interested parties are heard in the policy-making process. The third is rational policy making. The adoption of RIA helps in fostering regulations that increase the net welfare of the community [13]. This perspective is consistent with the civic republican theory $[14,15]$ which argues that, under proper conditions, actors in the regulatory system are able to systematically pursue the broader community interest. Thus, the use of RIA ensures the engagement of public interest groups, civil society organisations and citizens and enhances the likelihood that regulatory outcomes will be consistent with the requirements of the normative theory of regulation.

The aim of the RIA [16] is to determine the best option to achieve the objective of a rulemaking activity while minimising potential negative impacts. According to the Recommendation of the Council on Regulatory Policy and Governance [17], RIA is both a tool and a decision process for informing political decision makers on whether and how to regulate to achieve public policy goals. As a tool supporting decision making, RIA focuses on ensuring that a systematic and rigorous process of identification and assessment of the potential impacts of government actions is undertaken and on quantifying the expected costs and benefits of a regulatory measure; on assessing the effectiveness of the measure in achieving its policy goals; and on determining whether there are superior alternative approaches available to governments. As a decision process RIA complements other key elements of regulatory policy, such as public consultation, by developing a better understanding of the likely impact of regulatory options and communicating this information to policy makers, at a time and in a form that can be used to guide regulatory decision-making in relation to both proposed and existing regulations [18]. The Recommendation of the Council on Regulatory Policy and Governance [17] recommends that RIA be integrated into the early stages of the policy process in the formulation of new regulatory proposals and that ex ante assessments of regulatory costs, benefits and risks should be quantitative wherever possible.

RIA consists of a series of five logical steps that structure the analysis [16] problem identification, objective definition, option development, impact analysis and option comparison. Compliance cost assessment (CCA) is a significant element of Regulatory Impact Analysis (RIA), which is the broader analysis of all of the benefits and costs of a proposed regulatory initiative (or of existing regulations). The term "regulatory costs" as used by the OECD [19] embraces all of the costs attributable to the adoption of a regulatory requirement, whether direct or indirect in nature and whether borne by business, consumers, government and its respective authorities (i.e. taxpayers) or other groups. Fig. 1 sets out taxonomy of regulatory costs. 


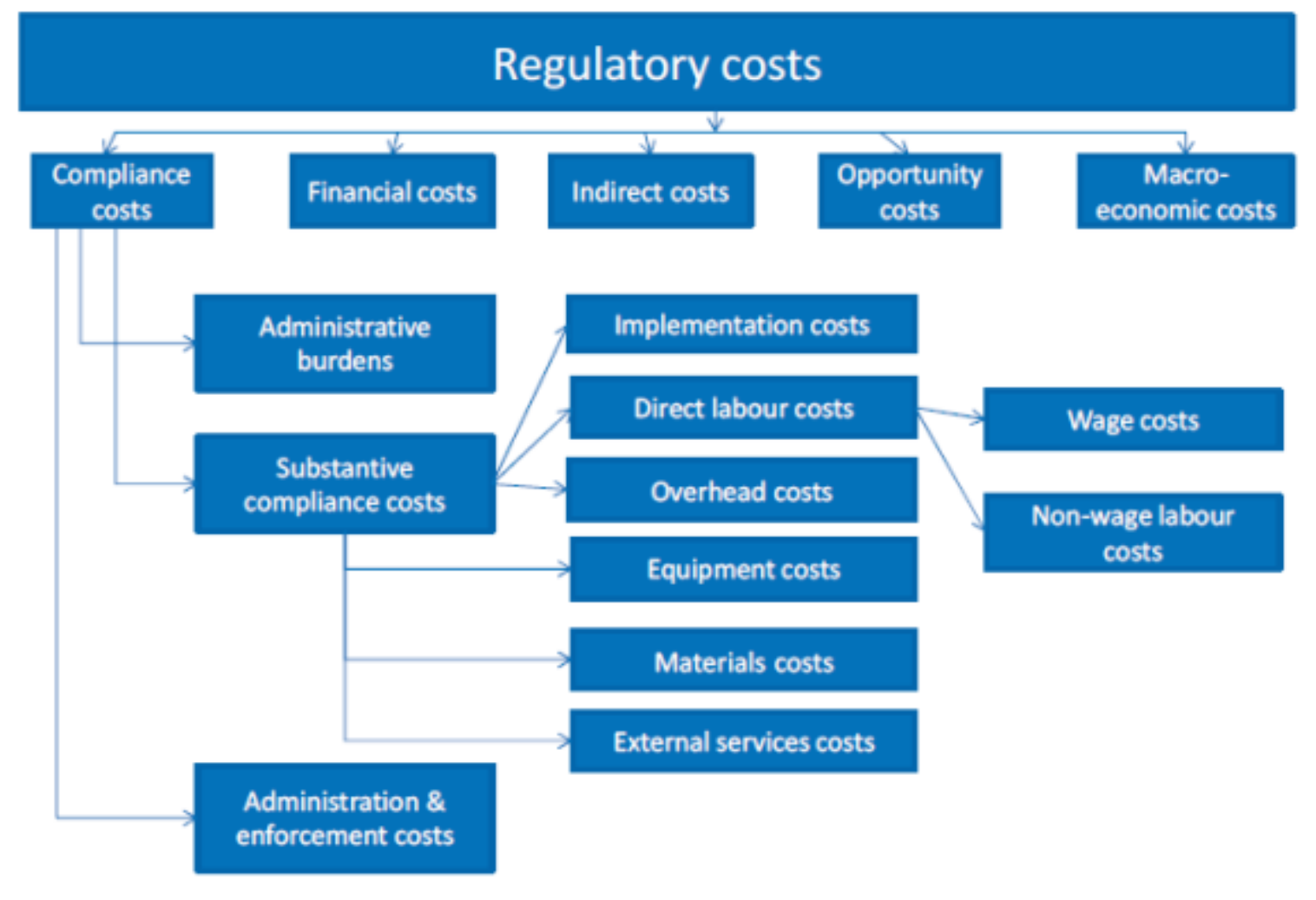

Source: OECD [19:11]

Fig. 1: Taxonomy of regulatory costs

\section{$3 \quad$ Results of the Research}

In connection with the determination of regulatory costs of the increase in lobbying transparency by means of the proposed measures (see Tab. 1), the basic project options are defined. The option with the most suitable solution should set such conditions for the performance of lobbying which will significantly contribute mainly [20:19]:

- to the definition of the term "lobbying",

- to the determination of a circle of people involved in lobbying (lobbyists) and of public officers whose conduct lobbyists influence,

- to setting up rules for transparent lobbying,

- to the general increase in the transparency of the decision-making and legislative process.

\subsection{Option 0 - Non-Transparent Lobbying}

The zero option represents a situation of the existence of non-transparent lobbying without adopting any measures for the increase in decision-making and legislative process transparency. The risk arising from retaining the non-transparency state is a negative impact on the creation of public policies and adoption of decisions from the view point of potential advancing of hidden interests or giving preference to certain interests over others and also on the public whose confidence in these processes decreases. Public decisions or activities of public institutions then lose their legitimacy. Other risks include democracy erosion, decrease of citizens' confidence in politicians, political parties and institutions. It can be assumed that the problems of the current condition will become worse and deeper, namely [20]:

- persisting low transparency of the legislative process which will lead to a gradual deterioration in the quality of legislation; 
- pressure coming from interests groups and aiming at reaching such legislation which would be advantageous mainly for the groups themselves;

- consequently to this, the quality of business environment will deteriorate. as well as the attractiveness of the CR not only for foreign investors (including the risk of international arbitrations due to breaches of agreement on the mutual protection of investments), but also for Czech companies (including the outflow of Czech companies headquarters out of the Czech Republic);

- low level of decision-making processes transparency (strategic planning, awarding tenders, etc.) in public administration (state administration and public corporations);

- low level of control over the influence on decision making of public authorities.

The costs of the zero option (see Tab. 2) can be quantified only with difficulty because in the environment of non-transparent lobbying it is only possible to indirectly quantify costs which are connected with advancing partial interests in legislation colliding with the public interest because such an activity remains hidden. The costs arising from this activity for the public sector can be quantified only by means of expert estimation. Direct costs would arise in the case of unsuccessful international arbitrations, in the case of reduced tax revenue caused by the outflow of businesses from the country, if a small business became more difficult to run or if the rating and evaluation of the country by the World Bank and the International Monetary Fund worsened, which would lead to the reduction of international investments. Giving up the efforts to make lobbying transparent would also mean disregarding the recommendation of international organizations (OECD, GRECO and The Council of Europe).

Tab. 2: Costs connected with Option 0 - non-transparent lobbying

\begin{tabular}{|l|l|}
\hline & $\begin{array}{l}\text { Compliance costs } \\
\text { retaining costs arising from the existing regulation (or their absence) which are a } \\
\text { result of lobbying for partial interests which are in contradiction with the public } \\
\text { interest, }\end{array}$ \\
- & costs and sanctions in the case of unsuccessful international arbitration, \\
- reduction of tax revenue, limitation of (foreign) investments. \\
Other regulatory costs \\
- retaining the existing level of (non)transparency of lobbying activities and \\
gradually deteriorating quality of legal regulations as a result, \\
failure to take into account recommendations of international organizations, \\
deterioration of the country's rating.
\end{tabular}

Source: Author, [20]

\subsection{Option I - Increase in Lobbying Transparency on the Part of Lobbyists}

This option represents adoption of measures for the increase in lobbying transparency which are performed on the part of lobbyists. Lobbyists are persons who systematically and in an organized way endeavour to influence the legislative process and decision-making of public officials [20]. They are entities (legal or natural persons) focusing primarily on lobbying (professional lobbyists include lobbyist consultants and associations, and legal counsels and law firms) and entities involved in lobbying as in supporting activities for the purpose of support of their main activity or business (in-house lobbyists, thus e.g. professional associations, non-profit organizations, etc.).

The proposed measures (see Tab. 1, measures 1 - 4) include Register, Codes of Conduct, Disclosure of activities and Open calendars. The individual measures can be realized by means of legislative regulations (legally binding and enforceable measures), or they may be left to the discretion of stakeholders (non-legislative measures). These measures belong 
among the most frequently used tools ensuring public control over lobbying activities and increasing lobbying transparency. The costs connected with Option I are summarised in Tab. 3.

Tab. 3: Costs connected with Option I - increase in lobbying transparency on the part of lobbyists

\begin{tabular}{|l|l|}
\hline & Compliance costs \\
costs of the establishment and operation of a register of lobbyists (in relation to the \\
definition of lobbying, definition of a lobbyist, extent of data and number of \\
lobbyists), \\
- financial and administrative costs of getting acquainted with the regulation, the \\
preparation and collection of data and their entry into the register, \\
costs of the collection of data for reports on activities and time for their entering \\
into the system (depending on the frequency and extent of the data), \\
- costs of the establishment of an open diary (depending on the frequency and extent \\
of the data), \\
cost of the preparation, processing and provision of information in the open diary \\
(depending on the frequency and extent of the data). \\
Other regulatory costs \\
- low frequency of reporting, providing out-of-date information, \\
possibility of inconsistent provision of data to the open diary, \\
the failure to impose complementary obligation on the subjects of lobbying so that \\
they had to report contacts with lobbyists, \\
limited ability of the supervisory authority to obtain knowledge of breaches of \\
regulation, \\
interference with the privacy of individuals by disclosing their data in the register \\
of lobbyists, \\
legal non-enforceability of compliance with codes and their rules (N), \\
possible origination of formalistic and complicated ethical codes (N), \\
weakening will to comply with the regulation, especially if not observed \\
collectively (N),
\end{tabular}

Note: (N) Measures of a non-legislative nature.

Source: Author, [20]

\subsection{Option II - Increase in Lobbying Transparency from the Point of View of Lobbying Targets}

The second option is focused on the increase in lobbying transparency on the side of lobbying targets. These are mainly the subjects of lobbying, i.e. public officers who include members of parliament, government members, high officials but also advisors and assistants of public officers (mainly of parliament members and senators) can be included. Depending on the width of the conception of lobbying also representatives of local governments, i.e. of municipalities and regions, could be included as subjects of lobbying who are also involved in decision making about significant issues of the public interest, e.g. public tenders, landscape planning, etc. [20].

Increase in lobbying transparency can be achieved by adopting measures $5-9$ (see Tab. 1), which are Codes of Conduct, Revolving doors, Conflict of interests, Disclosures of politicians/senior public employees, Appointment diaries. The individual measures may again 
take the form of legislative or non-legislative measures. In Tab. 4 the costs connected with Option II are defined.

Tab. 4: Costs connected with Option II - increase in lobbying transparency from the point of view of lobbying targets

\begin{tabular}{|l|l|}
\hline Compliance costs \\
- costs of the establishment and operation of a register (in relation to the definition \\
of lobbying, definition of a subject of lobbying, frequency and extent of data), \\
- costs of the collection of data and entering the data into the system, \\
- cost of establishing a public diary, \\
- diary, \\
- costs of the preparation, processing and provision of information into reports on \\
contacts, \\
- costs of establishing and functioning of a register of gifts under the Act on \\
Other regulatory costs \\
- high demands regarding the moral integrity of public officers, \\
- possibility of provision of irrelevant and incomplete data into the public diary, \\
- possibility of provision of irrelevant and incomplete data into the reports on \\
contacts, \\
- limitation of the efficiency of measures in the area of political and decision- \\
making processes in the case of a narrow definition of a subject of lobbying, \\
- limited ability of the supervisory authority to obtain knowledge of breaches of \\
regulation, \\
- legal non-enforceability of compliance with codes and their rules (N), \\
possible origination of formalistic and complicated ethical codes (N), \\
weakening will to comply with the regulation, especially if not observed \\
collectively (N), \\
- time-consuming process of creating and approving codes (N).
\end{tabular}

Note: $(\mathrm{N})$ measures of a non-legislative nature

Source: Author, [20]

\subsection{Option III - Increase in Lobbying Transparency by Means of Sunshine Principles}

In case of the third option, the increase in lobbying transparency is achieved by means of so called sunshine principles in legislative or non-legislative form. By means of adopting and complying with these rules, an increase in transparency is achieved in all decision-making and legislative processes in the whole society. Sunshine principles are defined in Tab. 1. They are measures 10 - 16, i.e. Rules on legislative process, Rules on decision-making, Rules on consultations, Legislative footprint, Open Government Data, Political parties funding and Freedom of information. The costs connected with Option III are given in Tab. 5. 
Tab. 5: Costs connected with Option III - increase in lobbying transparency in accordance with increase in transparency of decision-making and legislative processes

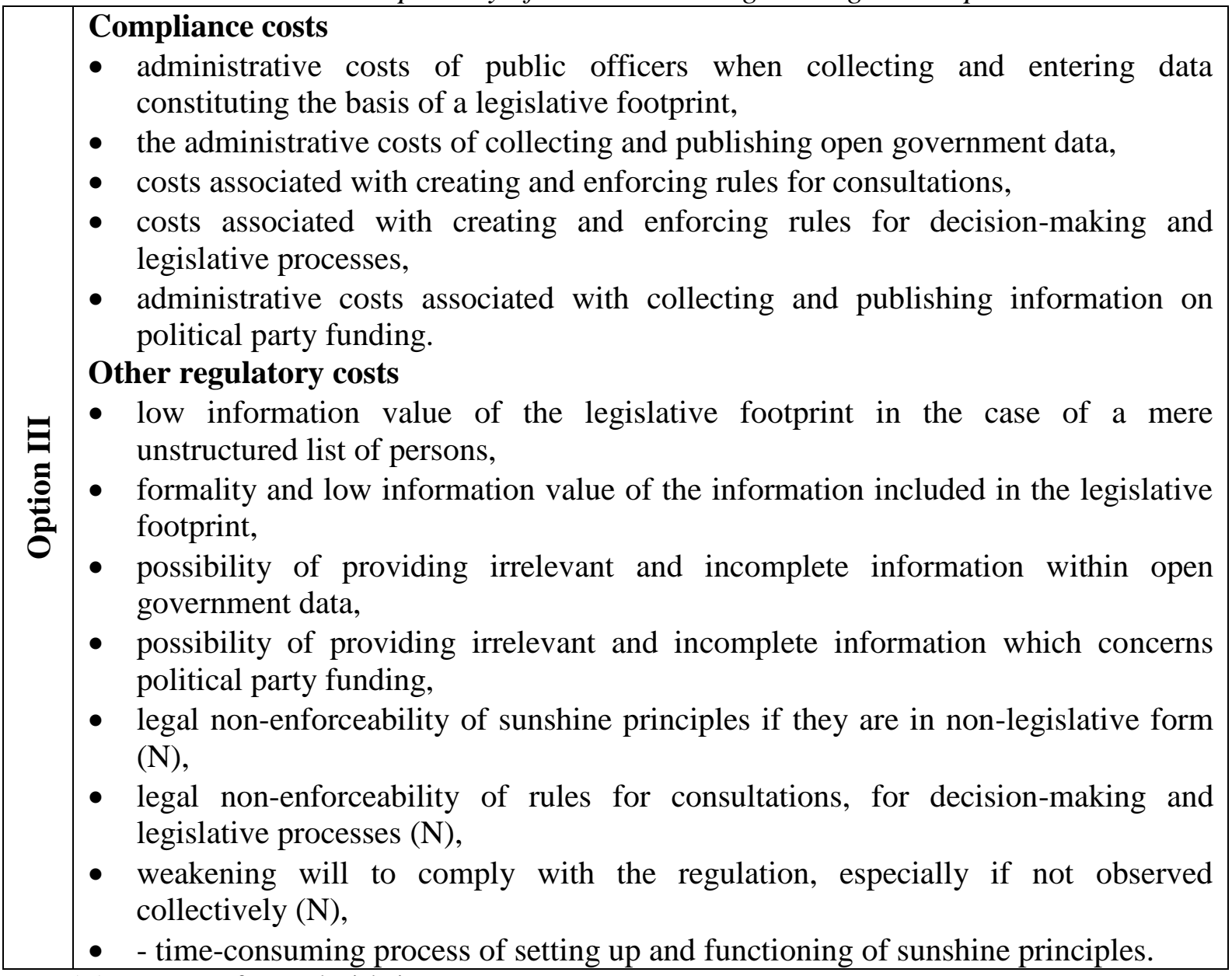

Note: $(\mathrm{N})$ measures of a non-legislative nature

Source: Author, [20]

\subsection{Option IV - Role of Monitoring and Sanctions in the Increase of Lobbying Transparency}

In the fourth option, the costs of an increase in lobbying transparency are connected with functional monitoring and sanctions, i.e. measures 17 and 18 (see Tab. 1). Oversight and Sanctions are mainly connected with the adoption of legislative measures and the costs are connected with establishing and functioning of an inspection authority and with imposing and enforcing sanctions laid down in the event of a breach of the rules. A certain level of control can also be performed even in the case of measures on non-legislative nature - costs are thus mainly spent on searching for and collecting information and its subsequent evaluation and publication. These costs are listed in Tab. 6. 
Tab. 6: Costs connected with Option IV - role of monitoring and sanctions in the increase of lobbying transparency

\section{Compliance costs}

- costs associated with the oversight of compliance with the measures and the related administration (depending on the definition of lobbying, the definition of a lobbyist, the definition of a subject of lobbying, the frequency and extent of the data),

- costs of comparing data from large databases needed to identify breaches of regulation,

- the costs of imposing sanctions,

- the costs of enforcing sanctions.

Other regulatory costs

- limited ability of the supervisory authority to obtain knowledge of breaches of regulation,

- possibility of providing irrelevant and incomplete information,

- - legal non-enforceability in the case of non-legislative type of regulation.

Note: $(\mathrm{N})$ measures of a non-legislative nature

Source: Author, [20]

\section{Conclusion}

The aim of the article was to determine options for lobbying transparency increase and their evaluation from the viewpoint of regulatory costs. As far as the evaluation of lobbying transparency increase is concerned, the most commonly used is Cost Benefit Analysis (CBA) which is the core method of Regulatory Impact Analysis (RIA). RIA is a systemic approach to critically assessing the positive and negative effects of proposed and existing regulations and non-regulatory alternatives. The used CBA method was specified on the basis of the delimitation of characteristics and attributes of transparent lobbying which are: 1) Direct rules focusing on lobbyists in term of lobbying activities, both legal and self-regulation, 2) Indirect rules targeting subjects of lobbying 3) Sunlight principles and/or anti-corruption tools and 4) The monitoring and sanctioning system. The individual measures may take the form of legislative or non-legislative measures.

First, Option 0 was defined as the existence of the current legislation and non-transparent lobbying. The costs of the zero option can be quantified only with difficulty because in the environment of non-transparent lobbying it is only possible to indirectly quantify costs which are connected with advancing partial interests in legislation colliding with the public interest because such an activity remains hidden. Option $\mathbf{I}$ is the possibility of increasing the transparency of lobbying by measures introduced on lobbyists. There are compliance costs and other regulatory costs related to the establishment and operation of Register, Codes of Conduct, Disclosure of activities and Open calendars. Option II represents an increase of transparency in terms of lobbying targets. Regulatory costs are associated with the implementation of Codes of Conduct, Revolving doors, Conflict of interests, Disclosures of politicians/senior public employees, Appointment diaries. Option III is defined as an increase in lobbying transparency in accordance with the increase in transparency of decision-making and legislative processes. The measures applied include Rules on legislative process, Rules on decision-making, Rules on consultations, Legislative footprint, Open Government Data, Political parties funding and Freedom of information. A large number of other regulatory costs are associated primarily with non-legislative measures. High administrative costs represent the largest component of compliance costs. In Option IV, the costs of an increase in lobbying transparency are connected with Oversight and Sanctions. The costs are connected 
with establishing and functioning of an inspection authority and with imposing and enforcing sanctions laid down in the event of a breach of the rules.

The proposed measures of lobbying transparency increase can work individually or in mutual combination, which can intensify their effects in practice. With regards to national specificities and historical approach it is necessary to thoroughly consider which of the possible measures should be applied and in what forms so that the expected results were ensured. The selection of the most suitable option (categories) will be done in relation with the presupposed acquired quantifiable and non-quantifiable benefits of lobbying transparency increase.

\section{Acknowledgements}

This article has been elaborated as one of the outcomes of research project supported by the Czech Science Foundation, project No. GA16-08786S "Impact of Transparency of Lobbying on Democratization and Its Consequences".

\section{Literature}

[1] GRAZIANO, L.: Lobbying, Pluralism, and Democracy. $1^{\text {st }}$ ed. Basingstoke: Palgrave. 2001. 248 p. ISBN 0333920562.

[2] Van SCHENDELEN, R.: Machiavelli in Brussels: The Art of Lobbying the EU. $1^{\text {st }}$ ed. Amsterdam: Amsterdam University Press. 2002. 344 p. ISBN 9053565795.

[3] COMMISSION OF THE EUROPEAN COMMUNITIES. (2006) Green Paper European Transparency Initiative. [online]. [accessed 2016-04-03] Available from WWW: http://europa.eu/documents/comm/green_papers/pdf/com2006_194_en.pdf

[4] LABOUTKOVÁ, Š.; ŽÁK, M.: Lobbování v Evropské unii a v České republice. Politická ekonomie. Praha: Oeconomica. 2010. 58(5), pp. 579-594. ISSN 0032-3233. DOI: $\underline{10.18267 / j . p o l e k .748}$

[5] OECD. (2013). Transparency and Integrity in Lobbying. [online]. [accessed 2016-1009] Available from WWW: https://www.oecd.org/gov/ethics/Lobbying-Brochure.pdf

[6] LABOUTKOVÁ, Š.; VYMĚTAL, P. (2018). Evaluation of Transparency of Lobbying as one of the Factors Reflecting the Institutional Quality. Journal of Public Policy. Under review.

[7] SIMON, H. A. (1955) A Behavioral Model of Rational Choice. The Quarterly Journal of Economics. 1955, 69(1), pp. 99-118. Available from WWW: http://www.jstor.org/stable/1884852?seq=1\#page_scan_tab_contents. $\underline{10.2307 / 1884852}$

[8] LAFFONT, J. J.; MARTIMORT, D. (2009). The Theory of Incentives: The Principal Agent Model. Princeton University Press, Princeton. ISBN 9781400829453.

[9] McCUBBINS, M. D.; NOLL, R. G.; WEINGAST, B. R.: Administrative Procedures as Instruments of Political Control. Journal of Law, Economics, \& Organization. 1987, 3(2), pp. 243-277. ISSN 87566222. DOI: 10.1093/oxfordjournals.jleo.a036930

[10] POSNER, E. A.: Controlling Agencies with Cost-Benefit Analysis: A Positive Political Theory Perspective. University of Chicago Law Review. 2001, 68(4), pp. 1137-1199. ISSN 00419494. DOI: 10.2139/ssrn.265655 
[11] MANLEY, J. F.: Neo-Pluralism: A Class Analysis of Pluralism I and Pluralism II. American Political Science Review. 1983, 77(2), pp. 368-383. ISSN 00030554. DOI: $\underline{10.2307 / 1958922}$

[12] ARNOLD, R. D.: Political Control of Administrative Officials. Journal of Law, Economics, \& Organization. 1987, 3(2), pp. 279-286. ISSN 87566222. DOI: $\underline{10.1093 / \text { oxfordjournals.jleo.a036931 }}$

[13] ARROW, K. J. et al.: Benefit-Cost Analysis in Environmental, Health and Safety Regulation. Washington, D.C.: American Enterprise Institute Press. 1996. ISBN 9780844770666.

[14] SUNSTEIN, C. R.: After the Rights Revolution: Reconceiving the Regulatory State. Cambridge, MA: Harvard University Press. 1993. ISBN 9780674009097.

[15] AYRES, I.; BRAITHWAITE, J.: Responsive Regulation: Transcending the Deregulation Debate. Oxford: Oxford University Press. 1992. ISBN 9780195093766.

[16] EASA. (2011). Regulatory Impact Assessment (RIA) Methodology. Available from WWW: https://www.easa.europa.eu/sites/default/files/dfu/rulemaking-docs-proceduresand-work-instructions-WI.RPRO.00046--Regulatory-Impact-Assessment-(RIA)Methodology.pdf

[17] OECD. (2012). Recommendation of the Council on Regulatory Policy and Governance. Paris: OECD Publishing. DOI: 10.1787/9789264209022-en

[18] OECD. (2009). Regulatory Impact Analysis: A Tool for Policy Coherence. Paris: OECD Publishing. DOI: $10.1787 / 9789264067110-1$-en

[19] OECD. (2014) OECD Regulatory Compliance Cost Assessment Guidance. OECD Publishing. DOI: $10.1787 / 9789264209657-e n$

[20] GOVERNMENT OFFICE OF THE CZECH REPUBLIC. (2017). Návrh věcného záměru zákona o lobbingu. Available from WW: https://www.komora.cz/legislation/11917-vecny-zamer-zakona-lobbingu-t-22-8-2017/

doc. PhDr. Ing. Pavla Bednáŕová, Ph.D. 


\section{NÁKLADY TRANSPARENTNÍHO LOBBINGU}

Zvyšování transparentnosti legislativního a rozhodovacího procesu včetně lobbistické činnosti snižuje riziko nepř́ípustného chování a omezuje negativní dopady, které mohou s lobbingem souviset. Cílem článku je stanovit varianty zvyšování transparentnosti lobbingu a vymezit související regulační náklady, tj. komplexní náklady na přijetí legislativních, př́padně nelegislativních opatření. $K$ hodnocení nákladů je využita metoda Cost-benefit analýzy (CBA), která je základním nástrojem Hodnocení dopadů regulace (RIA). Nulová varianta představuje situaci existence netransparentního lobbingu, první varianta přijetí opatření ke zvýšení transparentnosti, která jsou realizována na straně lobbistů. Druhá varianta je zaměřena na zvyšování transparentnosti na straně cílů lobbingu. V případě třetí varianty dochází ke zvyšování transparentnosti lobbingu na základě tzv. sunshine principles a zvyšování transparentnosti lobbingu prostřednictvím fungováním monitoringu a sankcí zahrnuje čtvrtá varianta. Pro jednotlivé varianty jsou definovány regulační náklady.

\section{KOSTEN FÜR TRANSPARENT LOBBYISMUS}

Die Steigerung der Transparenz des legislativen und Entscheidungsprozess inklusive der lobbyistischen Tätigkeit senkt das Risiko unzulässigen Verhaltens und begrenzt die negativen Auswirkungen, welche mit dem Lobbyismus zusammenhängen können. Das Ziel des Artikels besteht darin, Varianten der Steigerung der Transparenz des Lobbyismus festzulegen und die damit in Zusammenhang stehenden Regulierungskosten zu definieren, d. h. die komplexen Kosten zur Annahme legislativer bzw. nicht legislativer Maßnahmen. Zur Bewertung der Kosten kommt die Methode der Cost-benefit-Analyse (CBA) zur Anwendung, diese ist das Grundinstrument der Bewertung der Auswirkungen der Regulierung (RIA). Die Nullvariante repräsentiert die Existenzsituation des intransparenten Lobbyismus, die erste Variante die Ergreifung von Maßnahmen zur Steigerung der Transparenz, welche aufseiten der Lobbyisten umgesetzt werden. Die zweite Variante konzentriert sich auf die Steigerung der Transparenz aufseiten der Ziele des Lobbyismus. Im Falle der dritten Variante kommt es zu einer Steigerung der Transparenz des Lobbyismus auf Grundlage der sog. sunshine principles. Die Erhöhung der Transparenz des Lobbyismus durch das Funktionieren des Monitorings und der Sanktionen ist in der vierter Variante enthalten. Für die einzelnen Varianten werden die Regulierungskosten kalkuliert.

\section{KOSZTY TRANSPARENTNEGO LOBBINGU}

Zwiększanie transparentności procesu legislacyjnego i decyzyjnego, w tym działalności lobbingowej, zmniejsza ryzyko niedopuszczalnego zachowania i ogranicza negatywne skutki, jakie mogą być związane z lobbingiem. Celem niniejszego artykułu jest określenie możliwości podnoszenia transparentności lobbingu oraz ustalenie związanych z tym kosztów regulacyjnych, tj. kompleksowych kosztów przyjęcia działań legislacyjnych bądź też nielegislacyjnych. Do celów oceny kosztów wykorzystano metodę analizy kosztów i korzyści (CBA), będącą podstawowym narzędziem oceny skutków regulacji (RIA). Wariant zerowy oznacza sytuację istnienia nietransparentnego lobbingu, wariant pierwszy - przyjęcie działań na rzecz zwiększenia transparentności, realizowanych po stronie lobbystów. Drugi wariant dotyczy podnoszenia transparentności po stronie celów lobbingu. W przypadku wariantu trzeciego transparentność lobbingu rośnie na bazie tzw. sunshine principles, a czwarty wariant obejmuje zwiększanie transparentności lobbingu poprzez funkcjonowanie monitoringu i sankcji. Dla poszczególnych wariantów zdefiniowano koszty regulacyjne. 